\title{
Development and validation of a reverse transcription quantitative PCR for universal detection of viral hemorrhagic septicemia virus
}

\author{
Kyle A. Garver ${ }^{1, *}$, Laura M. Hawley ${ }^{1}$, Carol A. McClure ${ }^{2}$, Tamara Schroeder ${ }^{3}$, \\ Sandra Aldous ${ }^{3}$, Fiona Doig ${ }^{4}$, Michael Snow ${ }^{4}$, Sandra Edes ${ }^{1}$, Catherine Baynes ${ }^{1}$, \\ Jon Richard ${ }^{1}$
}

${ }^{1}$ Fisheries \& Oceans Canada, Pacific Biological Station, Nanaimo, British Columbia, V9T 6N7, Canada

${ }^{2}$ Atlantic Veterinary College, Charlottetown, Prince Edward Island, C1A 4P3, Canada

${ }^{3}$ Fisheries \& Oceans Canada, Freshwater Institute, Winnipeg, Manitoba, R3T 2N6, Canada

${ }^{4}$ Marine Scotland Science, Marine Laboratory, Aberdeen AB11 9DB, UK

\begin{abstract}
Viral hemorrhagic septicemia virus (VHSV) infects over 70 fish species inhabiting marine, brackish or freshwater environments throughout the Northern Hemisphere. Over its geographic range, 4 VHSV genotypes and multiple subtypes exist. Here, we describe the development and validation of a rapid, sensitive and specific real-time reverse transcription quantitative PCR assay (RT-qPCR) that amplifies sequence from representative isolates of all VHSV genotypes (I, II, III and IV). The pan-specific VHSV RT-qPCR assay reliably detects 100 copies of VHSV nucleoprotein RNA without cross-reacting with infectious hematopoietic necrosis virus, spring viremia of carp virus or aquatic birnavirus. Test performance characteristics evaluated on experimentally infected Atlantic salmon Salmo salar L. revealed a diagnostic sensitivity (DSe) $\geq 93 \%$ and specificity (DSp) $=100 \%$. The repeatability and reproducibility of the procedure was exceptionally high, with $93 \%$ agreement among test results within and between 2 laboratories. Furthermore, proficiency testing demonstrated the VHSV RT-qPCR assay to be easily transferred to and performed by a total of 9 technicians representing 4 laboratories in 2 countries. The assay performed equivalent to the traditional detection method of virus isolation via cell culture with the advantage of faster turnaround times and high throughput capacity, further suggesting the suitability of the use of this VHSV RT-qPCR in a diagnostic setting.
\end{abstract}

KEY WORDS: Viral hemorrhagic septicemia virus (VHSV) $\cdot$ Real time PCR $\cdot$ Diagnostic validation • Atlantic salmon · Proficiency testing $\cdot$ Reproducibility $\cdot$ Repeatability $\cdot$ Genotypes

\section{INTRODUCTION}

Viral hemorrhagic septicemia virus (VHSV) belongs to the family Rhabdoviridae, genus Novirhabdovirus (Tordo et al. 2005), and has been associated with significant losses of wild and cultured freshwater, estuarine and marine fish species. Since the initial isolation of VHSV in Denmark in 1963 (Jensen 1963), the virus has been detected in numerous European, Asian and North American countries. In addition, VHSV has an extremely broad host range and has been isolated from over 70 fish species (OIE 2009).

Because of the potential impact VHS disease poses to wild and farmed species, the virus has been the focus of considerable immunological, epidemiological and molecular biological studies. The virus contains a single-stranded, non-segmented negative sense RNA genome of 11 to $12 \mathrm{~kb}$ (Schütze et al. 1995, Betts \& Stone 2000, Ammayappan \& Vakharia 2009). The VHSV genome contains 6 genes that are in the $3^{\prime}$ to $5^{\prime}$ 
order encoding for the nucleocapsid- $(\mathrm{N})$, phospho- $(\mathrm{P})$, matrix- $(\mathrm{M})$, glyco- $(\mathrm{G})$, non-virion (NV) and polymerase (L) proteins, respectively. Upon infection of the host, the 6 genes are transcribed progressively from the $3^{\prime}$ to $5^{\prime}$ end of the template virus RNA and in decreasing molar abundances (Kurath \& Leong 1985). Thus, because of the primary position of the N-gene on the VHSV genome, $\mathrm{N}$ transcripts are most abundant during viral infection and therefore have been the target of several molecular assays used to detect VHSV (Batts et al. 1993, Chico et al. 2006, Lopez-Vazquez et al. 2006, Matejusova et al. 2008, Cutrin et al. 2009, Hope et al. 2010). The glycoprotein gene has also been a target of PCR-based detection methods (Bruchhof et al. 1995, Miller et al. 1998, Chico et al. 2006, Cutrin et al. 2009). However, because of the antigenic properties of the glycoprotein, it is also the gene used in a highly efficacious DNA vaccine (Lorenzen et al. 1998, 1999a). Therefore, diagnosis based on the VHSV G-gene sequence has the potential to be problematic in the event of vaccine use.

Phylogenetic studies of VHSV isolates have identified 4 discrete genetic groupings denoted as genotypes I to IV (Snow et al. 1999, Einer-Jensen et al. 2004). Moreover, these genotypes generally correlate with the geographical areas of isolation. Genotype I predominantly includes isolates from freshwater rainbow trout farms in continental Europe and a wide range of marine species in the Baltic Sea. Genotype II overlaps in range with genotype $\mathrm{I}$, and comprises marine isolates taken from Baltic specimens. Genotype III isolates have been recovered from wild and farmed fish in the North Sea as well as in the North and East Atlantic Ocean. Lastly, genotype IV represents isolates from North America, Japan and Korea (Nishizawa et al. 2002, Kim et al. 2003). Adding to the phylogenetic complexity of VHSV is the existence of multiple sublineages within the main genotypes resulting from the occurrence of multiple co-circulating strains within a particular geographic area. Therefore, it is imperative that detection methods are capable of recognizing all VHSV genotypes.

The standard detection method for VHSV is through virus isolation in cell culture, followed by definitive identification using either antibody- or nucleic-acidbased methods. The use of cell culture has become the 'gold standard' in that it allows for the detection of any VHSV genotype with one of a multitude of established susceptible cell lines (Lorenzen et al. 1999b). Moreover, virus detection using cell culture is the only methodology approved by the World Organisation for Animal Health (OIE) for use in direct surveillance programmes for obtaining approved VHS-free status. Despite the strength of cell culture as a primary VHSV diagnostic tool, the method has a significant drawback in that it can take up to $28 \mathrm{~d}$ to complete the assay. Consequently, cell culture methodologies can hinder monitoring programs where rapid results are required to effectively establish pathogen-free zones and thereby limit the spread of emerging VHSV strains.

To overcome the limitations posed by cell culture, molecular-based methodologies have been sought with the most recent being real-time reverse transcription quantitative PCR (RT-qPCR). The use of qPCR in the detection of micro-organisms in a research setting has been widely accepted (Mackay 2004). For use as a robust diagnostic tool, VHSV RT-qPCR must (1) be pan-specific for all known VHSV genotypes and sub-genotypes; (2) be sensitive, easy to perform and reproducible across laboratories; and (3) have wellcharacterized diagnostic test performance parameters (i.e. diagnostic sensitivity and specificity). To this end, we have developed a simple, highly reproducible, panspecific RT-qPCR for the detection of VHSV that has undergone diagnostic evaluation. Additionally, the performance characteristics of this VHSV RT-qPCR were compared with the traditional methodology of detecting VHSV using cell culture.

\section{MATERIALS AND METHODS}

Virus amplification. Viral isolates used in this study were propagated in epithelioma papulosum cyprini (EPC) cells (Fijan et al. 1983) with the exception of aquatic birnavirus (ABirn) which was amplified in Chinook salmon embryo (CHSE-214) cells (Lannan et al. 1984). Cell cultures were grown in 25 to $150 \mathrm{~cm}^{2}$ flasks (Nunc) containing minimum essential medium (MEM) (Gibco) supplemented with $10 \%$ fetal bovine serum (FBS), $1 \%$ GlutaMAX-1 and $0.06 \%$ sodium bicarbonate (Gibco) (MEM-10). To amplify virus, medium was decanted from flasks and cells were inoculated with stock virus at a multiplicity of infection of 0.001 . Inoculated cultures were incubated for $1 \mathrm{~h}$ at $15^{\circ} \mathrm{C}$ followed by the addition of 30 to $70 \mathrm{ml}$ of MEM supplemented with $2 \%$ FBS, $2 \%$ newborn calf serum, 14 mM HEPES, GlutaMAX-1, $0.03 \%$ sodium bicarbonate, $20 \mu \mathrm{g} \mathrm{ml}^{-1}$ Gentamicin and $1 \times$ Antibiotic-Antimycotic (Gibco) (MEM-4). Cultures remained at $15^{\circ} \mathrm{C}$ until complete destruction of the monolayer was observed. Cell culture supernatants were then harvested, centrifuged at $3100 \times g$ for $11 \mathrm{~min}$ and the clarified supernatants containing virus were aliquoted and stored at $-80^{\circ} \mathrm{C}$.

RNA extraction. Total RNA was extracted from either homogenized tissue (see below) or liquid samples using Trizol or Trizol LS reagents (Invitrogen), respectively. Tissue samples (50 to $100 \mathrm{mg}$ ) were homogenized with a Tissue Lyser (Qiagen) for 2 min at $25 \mathrm{~Hz}$ using a $5 \mathrm{~mm}$ stainless steel bead (Qiagen). 
Extractions were performed according to the manufacturer's protocol. RNA was resuspended in $50 \mu \mathrm{l}$ of water treated with diethyl pyrocarbonate (DEPC; Gibco). RNA suspensions were heated for $10 \mathrm{~min}$ at $55^{\circ} \mathrm{C}$, placed on ice and immediately quantified using the Nanodrop ND-100 (Nanodrop Technologies).

Primer/probe set design. To design an RT-qPCR primer pair and TaqMan minor groove binding (MGB) probe set that provides universal detection of VHSV, a conserved region within the $\mathrm{N}$-gene was identified permitting primer/probe binding regardless of genotype. The conserved region was identified through sequence alignment of all available published sequence data as well as from new sequence data produced in our laboratory. Three individual primer pairs and TaqMan MGB probe sets (Table 1), spanning nucleotides 913 to 1035 (numbering as in GenBank accession no. Y18263), were manually selected adhering to the guidelines for designing primers and probes used in TaqMan MGB quantification as outlined in the Primer Express Software 3.0 User Guide (Applied Biosystems). Probes (Applied Biosystems) contained 5' fluorescently labeled 6-carboxyfluorescein reporter dye and 3' MGB quencher. Primers (Operon) and probes were HPLC purified.

Preparation of in vitro transcribed VHSV RNA standards. RNA standards used for absolute quantification were in vitro transcribed from plasmids containing the $\mathrm{N}$ gene of VHSV. The N-gene coding region from each of $5 \mathrm{VHSV}$ isolates, of either genotype IVa or IVb, were amplified using forward primer 5'-TGA AAG TTG AAC ACA GAG TC-3' and reverse primer 5'-CTA TAT GAG TTA TGA GAC GG-3'. The 1323 bp PCR product from each of the 5 isolates was individually cloned into the plasmid pCRII-TOPO vector (Invitrogen) and transformed into DH5 $\alpha$ Max Efficiency chemically competent cells (Invitrogen) according to the manufacturer's protocol. Transformants were grown up in
Luria-Bertani (LB) broth and plasmid DNA was extracted using Qiagen's QIAquick miniprep spin kit. Clones were sequenced to verify orientation and accuracy. RNA transcripts were generated using a MEGAscript high yield SP6 transcription kit (Ambion) following the manufacturer's instructions. Briefly, $2 \mu \mathrm{g}$ of plasmid DNA was treated with $0.2 \mathrm{mg} \mathrm{ml}^{-1}$ proteinase at $50^{\circ} \mathrm{C}$ for $30 \mathrm{~min}$ followed by a phenol/chloroform extraction and then ethanol precipitation. Plasmids were linearized with $E C o R V$ at $37^{\circ} \mathrm{C}$ for $1 \mathrm{~h}$ and complete digestion was confirmed by electrophoresis on a $1.5 \%$ agarose gel containing $0.2 \times$ SYBR Safe (Invitrogen). Approximately $1 \mu \mathrm{g}$ of linearized plasmid was added to $20 \mu \mathrm{l}$ transcription reaction containing $5 \mathrm{mM}$ of each ribonucleotide and $2 \mu \mathrm{l}$ enzyme mix in $1 \times$ spermicidine buffer. Transcription reactions were incubated at $37^{\circ} \mathrm{C}$ for $4 \mathrm{~h}$ before $6 \mathrm{U}$ of TURBO DNase (Ambion) was added and returned to $37^{\circ} \mathrm{C}$ for $30 \mathrm{~min}$. To recover the RNA, each reaction underwent a Trizol LS extraction with the addition of $10 \mu \mathrm{g}$ of glycogen (Invitrogen) to the aqueous layer prior to isopropanol precipitation. A second DNase treatment was then conducted using Ambion's TURBO DNase kit. RNA suspensions were treated with $3 \mathrm{U}$ of TURBO DNase for $30 \mathrm{~min}$ at $37^{\circ} \mathrm{C}$, at which point another $3 \mathrm{U}$ was added and the reaction continued at $37^{\circ} \mathrm{C}$ for $30 \mathrm{~min}$. Digests were mixed throughout treatment. DNase reactions were inactivated according to manufacturer's protocol. To ensure RNA transcripts were DNA template free, VHSV RT-qPCR was conducted without the addition of reverse transcriptase. RNA transcripts were quantified using a Nanodrop ND-100. Copy number was then determined based on an $\mathrm{N}$-gene transcript molecular weight of $455910 \mathrm{~g} \mathrm{~mol}^{-1}$. One $\mu \mathrm{g}$ of $\mathrm{N}$ transcript contained $1.32 \times 10^{12}$ gene copies.

Reverse transcription. Synthesis of cDNA was generated using a high-capacity cDNA reverse transcription kit (Applied Biosystems) following the manufacturer's

Table 1. Primer and Taqman-MGB probe sets designed to amplify the viral hemorrhagic septicemia virus (VHSV) N gene. F and $\mathrm{R}$ denote forward and reverse primers, respectively. Locations are relative to VHSV GenBank accession no. Y18263. $T_{\mathrm{m}}$ : melting temperature; FAM: 6-carboxy fluorescein; MGBNFQ: minor-groove binding non-fluorescent quencher

\begin{tabular}{|c|c|c|c|c|c|}
\hline Primer and probe & Location & Nucleotide sequence $\left(5^{\prime}-3^{\prime}\right)$ & $T_{\mathrm{m}}\left({ }^{\circ} \mathrm{C}\right)$ & GC (\%) & Amplicon (bp) \\
\hline \multicolumn{6}{|l|}{ Set 1} \\
\hline $1 \mathrm{~F}$ & $913-935$ & TGG AAT CTC TTG TTG AGT CAG CC & 59.3 & 48 & \multirow{3}{*}{60} \\
\hline $1 \mathrm{R}$ & $954-972$ & CCT CCG ACA CCT GCC TCA T & 59.6 & 63 & \\
\hline 1-MGB & $936-949$ & FAM-AGG CGG ATC ATC CA-MGBNFQ & 68 & 57 & \\
\hline \multicolumn{6}{|l|}{ Set 2} \\
\hline $2 \mathrm{~F}$ & $954-972$ & ATG AGG CAG GTG TCG GAG G & 59.6 & 63 & \multirow{3}{*}{82} \\
\hline $2 \mathrm{R}$ & $1012-1035$ & TGT AGT AGG ACT CTC CCA GCA TCC & 59.6 & 54 & \\
\hline 2-MGB & $993-1010$ & FAM-TAC GCC ATC ATG ATG AGT-MGBNFQ & 68 & 44 & \\
\hline \multicolumn{6}{|l|}{ Set 3} \\
\hline $3 \mathrm{~F}$ & $935-952$ & CAG GCG GAT CAT CCA GCT & 58.3 & 61 & \multirow{3}{*}{79} \\
\hline $3 \mathrm{R}$ & $995-1013$ & CCG ACT CAT CAT GAT GGC G & 59.6 & 58 & \\
\hline 3-MGB & $954-970$ & FAM-ATG AGG CAG GTG TCG GA-MGBNFQ & 70 & 59 & \\
\hline
\end{tabular}


protocol. Briefly, $10 \mu \mathrm{l}$ of RNA extracted from cell-culture-amplified isolates or $1 \mu \mathrm{g}$ of RNA extracted from tissue samples was mixed with $1 \times$ RT buffer, $1 \times$ RT random hexamer primers, 4 mM dNTP mix and 50 U Multiscribe reverse transcriptase to a final volume of $20 \mu \mathrm{l}$. Reverse transcription reactions were run at $25^{\circ} \mathrm{C}$ for $10 \mathrm{~min}, 37^{\circ} \mathrm{C}$ for $2 \mathrm{~h}$ and $85^{\circ} \mathrm{C}$ for $5 \mathrm{sec}$. With each cDNA run, a VHSV-positive RNA and DEPC-treated water sample were included as positive and negative controls, respectively. All cDNA was stored at $-20^{\circ} \mathrm{C}$.

Primers/probe set screening and optimization. Primer/probe sets 1 to 3 (Table 1) were individually screened for their ability to amplify VHSV genotypes I, IVa and IVb (Table 2). RNA was extracted from VHSVinfected cell culture supernatant and subsequently used as template for cDNA synthesis as described above. Two $\mu l$ of cDNA template was added to the qPCR mixture, resulting in a $50 \mu$ reaction containing one of 3 primer/probe sets with primer/probe concentrations fixed at $800 \mathrm{nM}$ and $200 \mathrm{nM}$, respectively. Each reaction, including no template negative controls, was carried out in triplicate.

Subsequently, primer/probe set 2 concentrations were optimized using a VHSV genotype IVb isolate.

Table 2. Pan-specific detection of VHSV RT-qPCR assay. Primer/probe sets 1 to 3 were used in the initial assessment whereas the VHSV genotype range was expanded for primer/ probe set 2. $C_{\mathrm{t}}$ : cycle threshold. Genotypes are as described in Snow et al. (1999), Hedrick et al. (2003), Einer-Jensen et al. (2004, 2005), Lumsden et al. (2007) and Gagné et al. (2007)

\begin{tabular}{|c|c|c|c|c|}
\hline \multirow{2}{*}{ Isolate } & \multirow{2}{*}{ Genotype } & \multicolumn{3}{|c|}{ Mean $C_{\mathrm{t}}$ values } \\
\hline & & Set 1 & Set 2 & Set 3 \\
\hline 99-001 & IVa & 19.21 & 19.74 & 18.76 \\
\hline $99-292$ & IVa & 28.93 & 28.96 & 27.87 \\
\hline U13653 & $\mathrm{IVb}$ & 17.37 & 17.85 & 16.52 \\
\hline CA-NB00-01 & $\mathrm{IVb}$ & 15.49 & 16.65 & 15.04 \\
\hline $\mathrm{F} 1$ & Ia & 38.66 & 23.25 & 35.00 \\
\hline DK-3955 & Ia & & 20.16 & \\
\hline DK-6143 & Ia & & 18.72 & \\
\hline DK-f1 & Ia & & 19.55 & \\
\hline DK-9695152 & Ia & & 19.03 & \\
\hline FR-07-71 & Ia & & 19.85 & \\
\hline DK-1p40 & $\mathrm{Ib}$ & & 19.19 & \\
\hline DK-5p31 & $\mathrm{Ib}$ & & 20.8 & \\
\hline DK-M.Rhabdo & Ib & & 19.91 & \\
\hline DK-5p557 & II & & 37.01 & \\
\hline DK-1p49 & II & & 28.36 & \\
\hline DK5p551 & II & & 37.07 & \\
\hline DK-2p51 & III & & 20.91 & \\
\hline DK-4p51 & III & & 20.23 & \\
\hline UK-H17/1/95 & III & & 20.9 & \\
\hline UK 860/94 & III & & 20.59 & \\
\hline DK-4p168 & III & & 21.58 & \\
\hline UK6PT7 & III & & 20.26 & \\
\hline UK-6PT10 & III & & 20.62 & \\
\hline US-eby-wa93 & IVa & & 18.76 & \\
\hline US-pws-ak90 & IVa & & 17.48 & \\
\hline US-mak-wa88 & IVa & & 18.82 & \\
\hline
\end{tabular}

RT-qPCR reactions were conducted containing a series of primer dilutions ranging from 100 to $900 \mathrm{nM}$ in $100 \mathrm{nM}$ increments, while maintaining probe concentration at $200 \mathrm{nM}$. Similarly, optimal probe concentrations were determined by performing reactions containing dilutions of probe ranging from 50 to $500 \mathrm{nM}$ with primer concentrations held constant at $600 \mathrm{nM}$. Optimal primer/probe concentrations were selected based on the lowest cycle threshold $\left(C_{\mathrm{t}}\right)$ value and the highest final fluorescence value in the baselinecorrected, ROX-normalized view (dRn).

Optimized VHSV qPCR reaction parameters and cycling conditions. VHSV qPCR was performed using a Stratagene Mx3000P qPCR system. Each qPCR assay was conducted in a $25 \mu$ reaction containing $1 \mu \mathrm{l}$ of cDNA product, $600 \mathrm{nM}$ of each primer, $200 \mathrm{nM}$ probe and $12.5 \mu \mathrm{l} 2 \times$ TaqMan Universal PCR master mix (Applied Biosystems) and using the following thermocycle profile: $2 \mathrm{~min}$ at $50^{\circ} \mathrm{C}, 10 \mathrm{~min}$ at $95^{\circ} \mathrm{C}$ and 40 cycles of $15 \mathrm{~s}$ at $95^{\circ} \mathrm{C}, 1 \mathrm{~min}$ at $60^{\circ} \mathrm{C}$. VHSV qPCR data were analyzed using MxPro software (Stratagene). Replicates were analyzed individually using the adaptive baseline and amplification-based threshold algorithm enhancements. Raw fluorescence was also observed, ensuring that samples crossed with threshold between 3000 and 45000 fluorescence units.

VHSV RT-qPCR limit of detection. The analytical sensitivity and efficiency of the assay was evaluated using standard curves generated by amplification of in vitro transcribed VHSV N-gene RNA. Standard curves were constructed using 10-fold serially diluted RNA transcripts ranging from $10^{8}$ to 10 copies per qPCR reaction, with each dilution containing the addition of $1 \mu \mathrm{g}$ of background RNA (RNA extracted from VHSVfree Atlantic salmon kidney tissue). Each dilution of the RNA transcript was taken through the reverse transcription step and used as template in the qPCR assay. Six replicates of each dilution were run in the qPCR assay. To evaluate whether RNA transcripts are a suitable proxy for absolute quantification of VHSV infected tissue or cell culture material, reaction efficiencies generated from plasmid transcripts were compared with reactions containing either VHSV RNA from cell culture or tissue. Efficiencies for reactions containing VSHV RNA from cell culture or from tissue homogenate were determined from standard curves constructed from 10-fold dilution series of each RNA template assayed by qPCR in triplicate.

Analytical specificity of VHSV RT-qPCR. Primer/ probe set 2 was tested for cross reactivity to 2 related rhabdoviruses, infectious hematopoietic necrosis virus (IHNV 93-057 genogroup U; Kurath et al. 2003) and spring viremia of carp virus (SVCV HHOcarp06; Garver et al. 2007), and against an aquatic birnavirus (Abirn 89362; Tebb et al. 1991). At least $10^{5}$ plaque-forming 
units (pfu) of each cell culture amplified isolate was extracted. Ten $\mu \mathrm{l}$ of these total RNA extracts was tested individually and as an equal mix of RNAs that included VHSV RNA. The RT-qPCR assay was performed in triplicate using reaction conditions as stated above. Sequence similarity of primer/probe set 2 with VHSV sequences and other rhabdovirus $\mathrm{N}$ gene sequences was assessed through alignments using BioEdit (Fig. 1).

RT-qPCR pan-specific detection of VHSV. To assess the ability of primer/probe set 2 to amplify different VHSV genotypes, cDNA derived from cell culture amplified isolates from all 4 genotypes (Table 2) were used as templates in RT-qPCR.

Laboratory proficiency panel testing. VHSV proficiency panel preparation and characterization: To generate VHSV reference material, Atlantic salmon Salmo salar L. ( $480 \mathrm{~g})$ were injected intraperitoneally (i.p.) with isolate 99-292 at a dose of $5.9 \times 10^{5} \mathrm{pfu} \mathrm{fish}^{-1}$. Fish were monitored and fed for $38 \mathrm{~d}$ post challenge. Mortalities were immediately collected and anterior kidney was aseptically removed, placed in a bag and stored at $-80^{\circ} \mathrm{C}$ until processed. Concomitantly, a $0.1 \mathrm{~g}$ subsample was also taken from each kidney for prescreening using the VHSV RT-qPCR procedure as described above. Kidney samples with $C_{\mathrm{t}}$ values less than 29 were used as VHSV-positive tissues for the generation of proficiency panels. All positive kidney tissues were combined and homogenized using a polytron (Brickmann Instruments). A 10-fold dilution series from 1:10 to 1:10000 of the positive homogenate was made with the addition of VHSV negative kidney homogenate as diluent. Homogenates were aliquoted in $2 \mathrm{ml}$ safe-lock tubes (each containing $~ 70$ to $90 \mathrm{mg}$ of tissue), flash frozen in a dry ice ethanol bath and stored at $-80^{\circ} \mathrm{C}$. Prior to distribution of proficiency panel sets, specimens were internally tested using the VHSV RT-qPCR assay (as described above). Sample sets were tested after being taken directly from $-80^{\circ} \mathrm{C}$ storage as well as after $24 \mathrm{~h}$ of storage on dry ice in order to reflect overnight shipping conditions. Means \pm SD were calculated based on a minimum of 20 individual runs for each control sample. Control limits were established by means of Shewhart charts as described elsewhere (Shewhart 1931, Levey \& Jennings 1950, Westgard et al. 1981).

Participating laboratories, instructions and evaluation of results: Three external laboratories, collectively represented by 8 additional technicians, participated in VHSV RT-qPCR proficiency panel testing. Each proficiency panel consisted of 5 randomly selected samples that could be characterized as strong positives, weak positives and/or negative specimens. Panels were shipped on dry ice by guaranteed $24 \mathrm{~h}$ delivery to participating laboratories. Laboratories were notified electronically of the shipment and advised to store the panel at $-80^{\circ} \mathrm{C}$ upon receipt if not processing immediately. In addition to the samples, each participant received RNA extraction, cDNA production and qPCR amplification protocols and was instructed to submit their results electronically along with the details regarding primer/ probe and system manufacturer as well as any deviations in methods from the supplied protocols. Panel results were compiled and compared with the 'true' control value. Panel results were rejected if one or more control value exceeds control limits set as the mean $+2 \mathrm{SD}$.

Diagnostic validation of the VHSV RT-qPCR. To determine the diagnostic operating characteristics of the VHSV RT-qPCR, tests were performed on experimental groups of VHSV-infected and non-infected fish.

Fish: Atlantic salmon (Mowi strain) parr were moved from a freshwater hatchery with no previous occurrence of VHSV to the Pacific Biological Station, Nanaimo, British Columbia. Fish were held in ambient pathogen-free freshwater and subsequently acclimated to seawater (smolted) by increasing the seawater:freshwater ratio by $25 \%$ every 4 to 5 d. Fish were fed a semi-moist pelleted diet (BioOregon) daily, at $1.5 \%$ of their body weight.

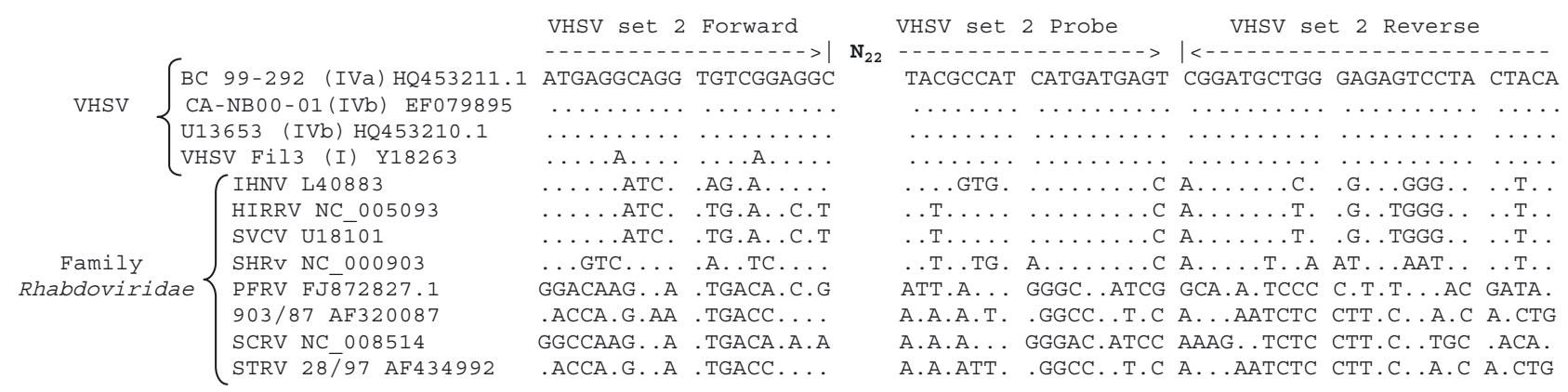

Fig. 1. Partial nucleoprotein (N-gene) alignment of VHSV and related aquatic rhabdoviruses. 903/87: trout rhabdovirus 903/87; HIRRV: hirame rhabdovirus; IHNV: infectious hematopoietic necrosis virus; PFRV: pike fry rhabdovirus; SCRV: Siniperca chuatsi rhabdovirus; SHRv: snakehead rhabdovirus; STRV 28/97: sea trout rhabdovirus 28/97; SVCV: spring viremia of carp virus. Viral abbreviations are followed by their GenBank accession numbers and the location and direction of primer/probe set 2 are denoted by arrows 
VHSV challenge: To generate a population of VHSV infected fish, 63 Atlantic salmon smolts (mean weight $223 \mathrm{~g} \mathrm{fish}^{-1}$ ) were i.p. injected with $1 \times 10^{4} \mathrm{pfu} \mathrm{fish}^{-1}$ of VHSV isolate 99-292 (genotype IVa). For a population of non-infected fish, 50 Atlantic salmon were left unhandled and maintained in a separate tank. Fish were held in a $750 \mathrm{ltank}$ with $8^{\circ} \mathrm{C}$ seawater. At 3, 5, 7, 10 and $11 \mathrm{~d}$ post challenge, 10 fish each from the viruschallenged and negative control tanks were killed with an overdose of tricaine methane sulphonate (MS222). Fish were placed immediately on ice, individually bagged and labeled using a computer-generated random number so that the treatment group was unknown to the laboratory testers.

Tissue sampling, RT-qPCR analysis and virus isolation: Anterior kidneys were aseptically removed and longitudinally quartered. From each of the kidney sections, a subsample of 30-50 mg was taken, individually placed in $2 \mathrm{ml}$ tubes containing $1 \mathrm{ml}$ of RNA later (Ambion), stored overnight at $4^{\circ} \mathrm{C}$ and then transferred to $-20^{\circ} \mathrm{C}$ until testing for VHSV by RTqPCR. The remaining longitudinal sections, ranging from 0.20 to $0.98 \mathrm{~g}$, were individually stored in bags at $-80^{\circ} \mathrm{C}$ until assayed for VHSV using cell culture. To determine the repeatability and reproducibility of both the VHSV RT-qPCR and cell culture virus isolation assay, duplicate samples were processed using each assay within each of the 2 laboratories. Thus, 4 kidney samples (2 for RT-qPCR and 2 for virus isolation analysis) from each of the 100 fish (50 VHSVinjected and 50 non-injected) were shipped by courier overnight on dry ice to an external laboratory while the duplicate set of 400 kidney pieces remained at the Pacific Biological Station for analysis by RT-qPCR and cell culture. A schematic representation of the tissue sampling is presented in Fig. 2. Detection of VHSV via RT-qPCR was performed as described above. Cell culture virological testing utilized mycoplasma-free EPC cell stocks (maintained as described in 'Virus amplification'). Cell stocks were also tested for VHSV susceptibility prior to use in virological assay. Virological assays were carried out as follows. Kidney tissue was thawed and homogenized in Hanks' balanced salt solution + antibiotics (Gibco) using a Seward stomacher (60 s, high speed). A $2 \%$ dilution was prepared and filtered $(0.45 \mu \mathrm{m})$ into a $2 \mathrm{ml}$ microtube. Medium was removed from the 24 -well plates containing newly seeded (within $24 \mathrm{~h}$ ) EPC cells. To each plate, $100 \mu \mathrm{l}$ sample filtrates were inoculated in duplicate. Plates were incubated at $15^{\circ} \mathrm{C}$ for 30 to $60 \mathrm{~min}$ and then overlaid with MEM-4 (1 ml well $\left.{ }^{-1}\right)$. Plates were incubated at $15^{\circ} \mathrm{C}$ and examined within $72 \mathrm{~h}$ (usually within $24 \mathrm{~h}$ ) of inoculation. Assay plates were then examined twice a week for viral cytopathic effect (CPE).

Quality controls: During diagnostic validation of the VHSV RT-qPCR, various quality controls were employed to monitor reaction efficiencies and ensure scientific integrity. At each stage of the VHSV RTqPCR assay (i.e. cDNA synthesis and qPCR) at least one positive and one negative control was included. Moreover, positive and negative controls performed in the initial stages were carried through each subsequent stage until the final qPCR run. All VHSV-positive control material was of genotype IVb, thereby allowing it to be readily distinguished from the validation samples infected with VHSV genotype IVa. For cDNA synthesis, the positive control consisted of $1 \mu \mathrm{g}$ of RNA extracted from Atlantic salmon kidney spiked with VHSV IVb whereas the negative control was DEPC water only (no RNA). Finally, for the VHSVqPCR portion of the assay, a low and high positive con-

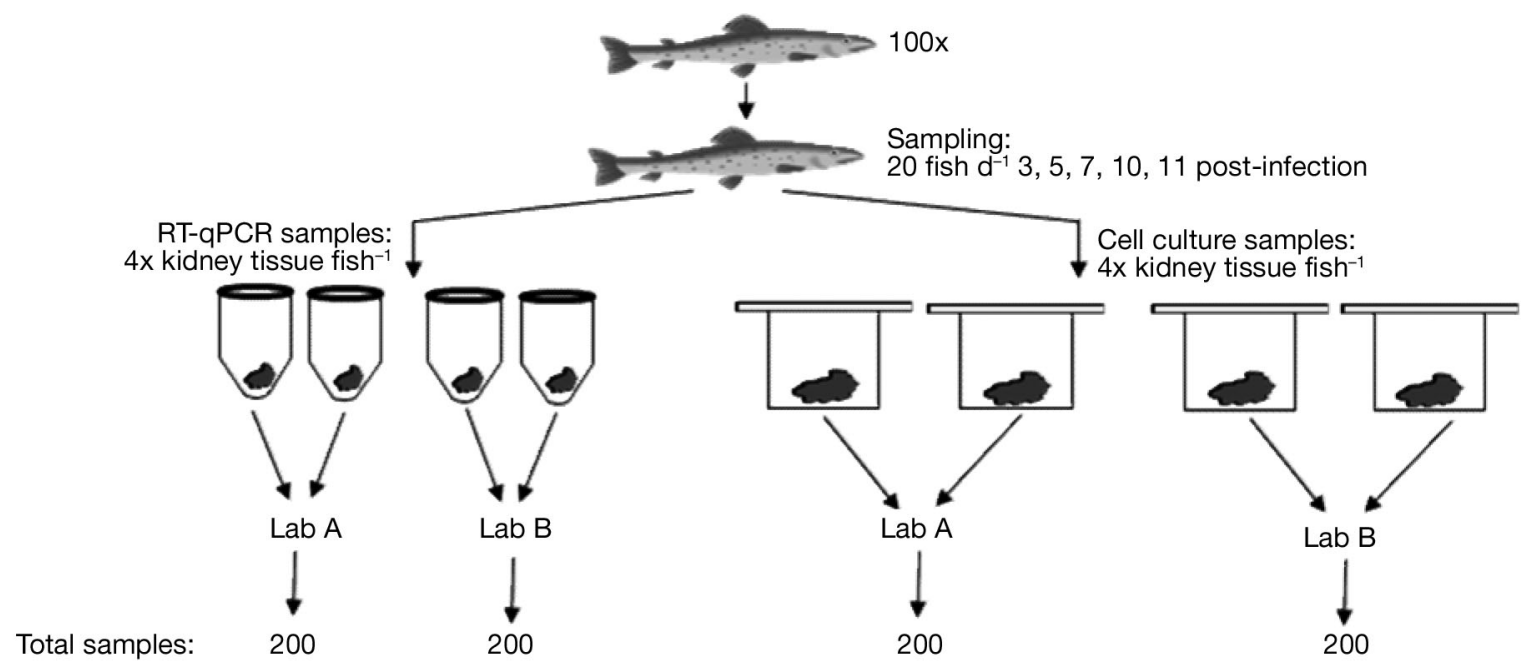

Fig. 2. Total number of fish, tissue samples and diagnostic tests performed to evaluate the diagnostic operating characteristics of the VHSV real-time reverse transcription quantitative PCR (RT-qPCR) and virus isolation on cell culture 
trol was included such that one reaction contained VHSV-IVb positive cDNA at $5 \times 10^{6}$ copies $\mathrm{\mu l}^{-1}$ (high) and another contained $2.5 \times 10^{2}$ copies $\mu^{-1}$ (low). These reactions were expected to generate $C_{\mathrm{t}}$ values of 20.8 and 35.9, respectively. Negative qPCR controls were included with each run and consisted of DEPC water only (no cDNA). In addition to the specific RTqPCR stage controls, an endogenous control (ELF1 $\alpha$ ) was employed to verify RNA integrity within each individual sample. This was evaluated through a separate qPCR assay targeting the translation elongation factor 1 alpha (ELF1 $\alpha$ ) performed as described by Snow et al. (2006). During RNA extractions of Atlantic salmon kidney specimens, a negative control consisting of DEPCtreated water was also included.

Diagnostic characteristics of VHSV RT-qPCR and virus isolation: The diagnostic sensitivity (DSe), the proportion of diseased animals that tested positive, and the diagnostic specificity (DSp), the proportion of nondiseased animals that tested negative, were calculated using a $2 \times 2$ table, as described by McClure et al. (2005). Disease status of the specimens was defined using 2 different approaches. The first approach utilized virus isolation as a gold standard test to evaluate the RT-qPCR. The second approach established a pseudo-gold standard via a compilation of 8 test results to evaluate both the RT-qPCR and virus isolation assays.

Use of a gold standard: The disease status of the 50 non-infected fish and 50 VHSV-injected fish was defined based on the series interpretation of the virus isolation results from the 2 sets of tissues from the same fish performed at Laboratory A. A fish was considered positive if both virus isolation results were positive.

Use of a pseudo-gold standard: As part of the diagnostic evaluation of these tests, each fish was tested 8 times (Fig. 2). All positive tests for each fish were tallied and a histogram was created. A pseudo-gold standard (Dohoo et al. 2009) was developed by finding a biologically reasonable cut-off point for the total number of positive tests necessary to deem a fish as VHSV positive.

Diagnostic repeatability and reproducibility of VHSV RT-qPCR and virus isolation: Duplicate samples of 100 fish were submitted to the laboratories to evaluate the repeatability (within laboratory variation) for each assay method employed (RT-qPCR and virus isolation). The results from the full set of 200 samples from each assay were also compared between laboratories to determine reproducibility (agreement between the same assays performed at different laboratories). The repeatability and reproducibility of each assay were assessed by determining the proportion of the testing pairs that concurred. RT-qPCR results were distinguished as positive or negative based on a $C_{\mathrm{t}}$ cut- off value of 38 . Thus, samples with $C_{\mathrm{t}}$ values $>38$ were considered negative. The results from the 2 assays were tabulated in individual $2 \times 2$ tables whereby proportion agreement $=(\mathrm{a}+\mathrm{d}) /(\mathrm{a}+\mathrm{b}+\mathrm{c}+\mathrm{d})$ (Table 3$)$. Kappa or Cohen's kappa, $\kappa=2(\mathrm{ad}-\mathrm{bc}) /[(\mathrm{a}+\mathrm{b}) \times(\mathrm{c}+$ d) $+(b+d) \times(a+c)]$, was used to take into account the agreement that is due to chance (Cohen 1960). The kappa value classification scheme as proposed by Landis \& Koch (1977) was followed with kappa values $\geq 0.81$ considered almost perfect agreement. Prior to estimating kappa, McNemar's test, $\chi^{2}=(b-c)^{2} /(b+c)$, was used to examine whether both tests have approximately the same proportion of positive test results. If McNemar's test result is significant, then disagreement between the test results is occurring and the corresponding kappa is not a useful measurement because the tests cannot possibly agree (Dohoo et al. 2009).

Within- and between-laboratory variability of VHSV RT-qPCR $C_{t}$ values: Concordance correlation coefficients (CCC) were calculated as described by Lin $(1989,2000)$ to determine the variability in the $C_{\mathrm{t}}$ value reported for duplicate sample sets assayed at each of 2 laboratories (Laboratories A and B). The plot of the $C_{\mathrm{t}}$ values of one test against another was used to assess the accuracy and precision of the data. The graph of perfect concordance would yield a $45^{\circ}$ straight line. A reduced major axis was created by the linear regression line of the test results. The accuracy of the data is assessed by the closeness of the data's reduced major axis to the line of perfect concordance whereas the precision is assessed by how tightly the data clusters around the reduced major axis. Only fish that had $C_{\mathrm{t}}$ values $\leq 38$ for both sample pairs were included in the analyses.

Agreement of the $C_{\mathrm{t}}$ values was also calculated using Bland and Altman limits-of-agreement method (Bland \& Altman 1986, Barnhart et al. 2007). The means \pm SD of the test pairs were used to calculate the limits of agreement (mean $\pm 1.96 \mathrm{SD}$ ). A plot of the differences between test pairs against the mean value of the test pairs was used as a visual assessment of overall mean difference, range of test pair differences or outliers, or to determine whether the test pair differences vary with the mean $C_{\mathrm{t}}$ value (Dohoo et al. 2009).

Table 3 . The $2 \times 2$ table for determining assay repeatability and reproducibility

\begin{tabular}{|lccc|}
\hline \multirow{2}{*}{ Test 1} & \multicolumn{3}{c|}{ Test 2} \\
\cline { 2 - 4 } & Positive & Negative & Total \\
\hline Positive & $\mathrm{a}$ & $\mathrm{b}$ & $\mathrm{a}+\mathrm{b}$ \\
Negative & $\mathrm{c}$ & $\mathrm{d}$ & $\mathrm{c}+\mathrm{d}$ \\
Total & $\mathrm{a}+\mathrm{c}$ & $\mathrm{b}+\mathrm{d}$ & $\mathrm{a}+\mathrm{b}+\mathrm{c}+\mathrm{d}=\mathrm{n}$ \\
\hline
\end{tabular}




\section{RESULTS}

\section{Primer/probe set screening and optimization}

As a preliminary screen of primer/probe suitability in detecting VHSV isolates, each of the 3 primer/probe sets were evaluated for their ability to detect cell-culture-amplified isolates of genotypes I, IVa and IVb (Table 2). Of the 3 primer/probe sets tested, only sets 2 and 3 were capable of detecting each of the 3 genotypes. Set 1 was able to amplify the North American genotype (IVa and IVb); however, it was unable to recognize the European genotype I isolate (Table 2). Out of primer/probe sets 2 and 3, set 2 was superior in its sensitivity (lower $C_{\mathrm{t}}$ value) for the type I isolate while maintaining the ability to detect each of the sub-genotype IV isolates (Table 2). Because of amplification of genotypes I, IVa and b, primer/probe set 2 was selected for further optimization.

VHSV RT-qPCR reactions containing dilution series of set 2 indicated that $600 \mathrm{nM}$ of each primer and $200 \mathrm{nM}$ probe produced optimal VHSV amplification detecting VHSV at the lowest $C_{\mathrm{t}}$ with the highest $\mathrm{dRn}$ (Fig. S1 in the supplement, available at www.int-res.com/articles/suppl/ d095p97_supp.pdf).

\section{Reaction efficiencies, absolute quantification and limit of detection}

Amplification efficiencies of reactions containing VHSV RNA from plasmid transcription, cell culture or tissue ranged from -3.19 to $-3.55\left(\mathrm{R}^{2} \geq\right.$ 0.991) with a maximum difference in slope of 0.36 between the different templates. Because the amplification efficiencies of RNA transcript were similar to those for cell culture amplified virus and infected tissue, RNA transcript was deemed a suitable template to determine the RT-qPCR limit of detection.

The sensitivity of the VHSV RTqPCR with primer/probe set 2 was evaluated using dilution series of synthetic transcripts derived from 3 separate clones each representing a VHSV isolate originating from the west coast (genotype IVa), Great Lakes (genotype IVb) or east coast (genotype IVb) of North America. Irrespective of the transcript type, the VHSV RT-qPCR assay showed reliable amplification over 7 orders of magnitude, ranging from $1.0 \times 10^{8}$ to 100 copies (Fig. 3A). When the VHSV $\mathrm{N}$-gene transcript was diluted to 50 copies, 6 out of 6 replicates amplified within 40 cycles (mean $\pm \mathrm{SD} C_{\mathrm{t}}=$ $37.7 \pm 0.72$ ); however, amplifications at $C_{\mathrm{t}}$ values $>38$ produced minimal change in normalized fluorescence, such that true amplification was not confidently discerned (Fig. 3B). The lack of detection was further observed with 10 copies, with none of the 6 replicates producing a detectable amplicon at a $C_{\mathrm{t}}$ value $\leq 38$. Because of inconsistent amplifications and to avoid inclusion of false-positive test results (Type I error) in our study, a $C_{\mathrm{t}}$ cut-off value of 38 was established as the positive threshold of the assay.

RT-qPCR reaction efficiencies were comparable between the 3 different genotype IV transcripts, with slopes ranging from -3.31 to -3.55 and a maximum dif-

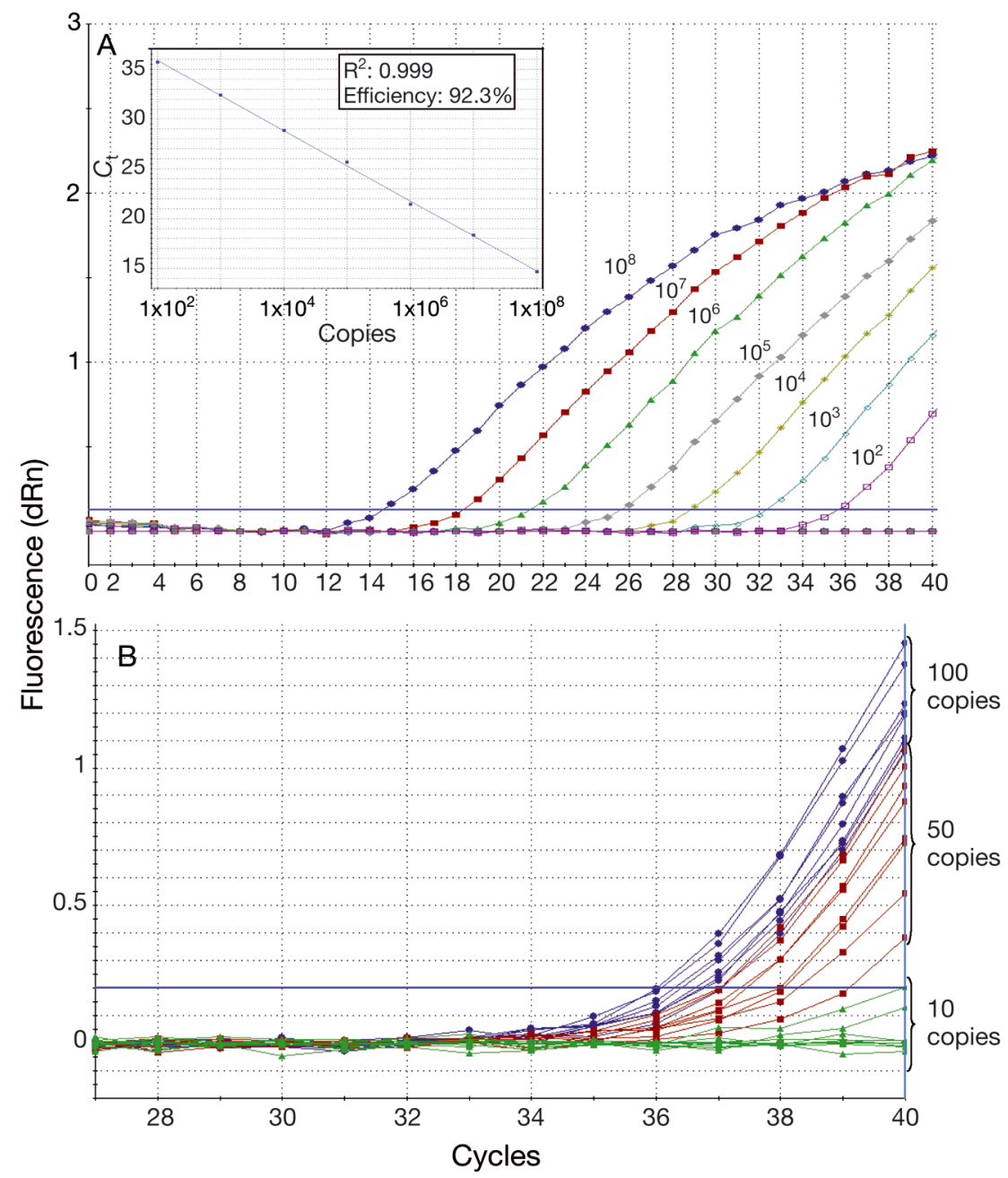

Fig. 3. VHSV RT-qPCR limit of detection MxPro amplification plots (horizontal blue line: detection threshold). (A) VHSV transcript standard ranging from $10^{8}$ to 100 copies reaction ${ }^{-1}$, inset with the standard curve, $R^{2}$ and efficiency values. (B) 100, 50 and 10 copies of VHSV transcript 
pating laboratories. Moreover, technicians receiving high and/or low VHSV positive tissue specimens reliably identified them within 2 standard deviations of the expected control value. Laboratories B and C conducted testing utilizing the protocols as described herein with the exception that primer pair set 2 was acquired through a different supplier, and Laboratory D utilized an alternative RNA extraction kit and PCR platform (Table 5).

\section{Diagnostic validation results}

All test results were put into a matrix with test method identity listed on the left and treatment group and fish identity listed across the top (Fig. 4).

\section{Gold standard estimate of DSe and DSp}

Of the 50 VHSV-injected fish, 30 were deemed positive using virus isolation test results from Laboratory A as the gold standard. Of the remaining 20 VHSVinjected fish not shown to be positive, 18 were designated as negative based on concordant results and 2 were deemed negative based on discordant results. All 50 fish in the non-injected treatment group were deemed negative. Overall, out of the 100 fish analyzed,
Laboratory A virus isolation results identified 30 fish as VHSV positive and 70 fish as VHSV negative. DSe and DSp of the universal VHSV RT-qPCR were estimated based on these sample designations.

DSe values from the 2 sets of RT-qPCR tests from Laboratory A were similar, with values differing by only $3.3 \%$ (Table 6 ). The $95 \%$ confidence intervals ranged from 73.5 for the low of set 2 up to $99.2 \%$ for set 1. DSp values were high (100\%) for both sets, as there were no false positives for either sample set.

\section{Pseudo-gold standard estimate of DSe and DSp}

To create the pseudo-gold standard, all positive results from the 8 different tests were tallied for each fish (Fig. 5). As there was a natural divide at 4 positive tests for each individual fish, fish having 4 or more positive tests were classified as positive pseudo-gold references whereas fish having 3 or less positive tests were designated as negative pseudo-gold references. A total of 28 pseudo-gold positive reference fish were identified. All 28 pseudo-gold positives correlated with the positives identified by the traditional gold standard approach. Additionally, 2 of the VHSV-positive reference fish identified by the traditional gold standard approach were defined as negative by the pseudo-gold standard.

Table 5. Laboratory VHSV RT-qPCR test characteristic deviations from protocol used in Laboratory A

\begin{tabular}{|c|c|c|c|c|c|c|}
\hline Laboratory & RNA extraction & cDNA synthesis & $\mathrm{qPCR}$ & Primer supplier & Probe supplier & Platform \\
\hline A & Trizol reagent & $\begin{array}{l}\text { ABI high capacity } \\
\text { cDNA reverse } \\
\text { transcription kit }\end{array}$ & $\begin{array}{l}\text { ABI } 2 \times \text { TaqMan } \\
\text { Universal master } \\
\text { mix }\end{array}$ & Operon & $\mathrm{ABI}$ & $\begin{array}{l}\text { Stratagene } \\
\text { Mx3000P }\end{array}$ \\
\hline B & - & - & - & Sigma & - & - \\
\hline $\mathrm{C}$ & - & - & - & Sigma & - & - \\
\hline $\mathrm{D}$ & $\begin{array}{l}\text { Qiagen } \\
\text { MagAttract RNA }\end{array}$ & - & Quantase & $\mathrm{ABI}$ & - & ABI Prism 7000 \\
\hline $\mathrm{D}$ & $\begin{array}{l}\text { Tissue Mini } \\
\text { M48 Kit }\end{array}$ & - & SensiMix & $\mathrm{ABI}$ & - & ABI Prism 7000 \\
\hline
\end{tabular}

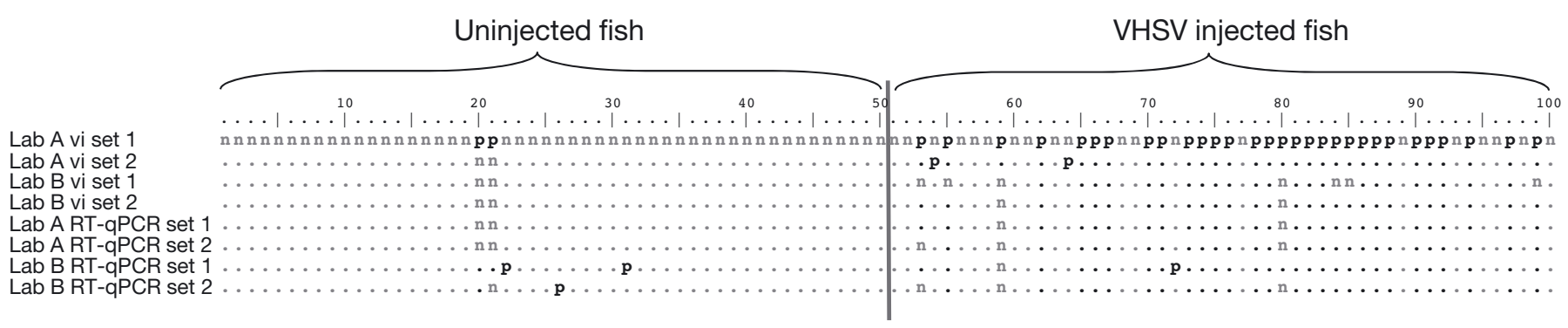

Fig. 4. Alignment of VHSV RT-qPCR and virus isolation test results by fish identity. p: positive results; n: negative results; vi: virus isolation. Test results concordant with the top result line are indicated by dots 
DSe and DSp for both virus isolation and RT-qPCR were very high (all over $94 \%$ ) and are presented in Table 7. The DSe value of the universal VHSV RTqPCR was higher when using the pseudo-gold stan-

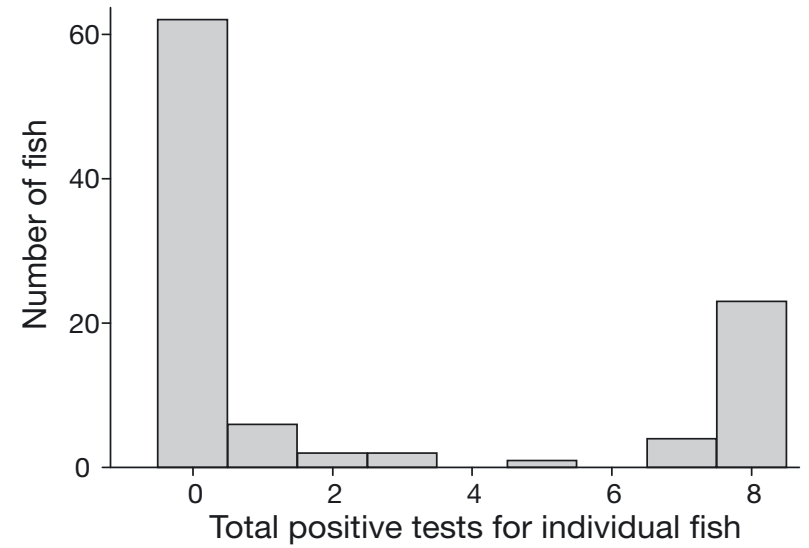

Fig. 5. Number of positive test results for each fish out of the 8 identical samples tested

Table 6. Diagnostic sensitivity and specificity of the VHSV RT-qPCR in Laboratory A using the gold standard for the 2 groups of repeated samples. +: VHSV positive; -: VHSV negative

\begin{tabular}{|c|c|c|c|c|c|c|}
\hline \multirow[t]{2}{*}{ Sample set } & \multicolumn{4}{|c|}{$\begin{array}{l}\text { Gold standard, } \\
\text { RT-qPCR result }\end{array}$} & \multicolumn{2}{|c|}{$\begin{array}{l}\text { Diagnostic test performance }(95 \% \\
\text { exact binomial confidence interval) }\end{array}$} \\
\hline &,++ &,-- &,-+ &,+- & Sensitivity (\%) & Specificity (\%) \\
\hline 1 & 28 & 70 & 0 & 2 & $93.30(77.90,99.20)$ & $100(94.90,100)$ \\
\hline 2 & 27 & 70 & 0 & 3 & $90(73.50,97.90)$ & $100(94.90,100)$ \\
\hline
\end{tabular}

dard versus the traditional gold standard because of a reduced number of false-negative reference fish when using the pseudo-gold standard.

\section{Repeatability and reproducibility of RT-qPCR and virus isolation}

The repeatability and reproducibility for the RTqPCR test was assessed using the proportion of samples in agreement and Cohen's kappa (Table 8). Agreement proportions for both laboratory repeatability and reproducibility equaled or exceeded $93 \%$. The kappa values were also extremely high, with almost perfect agreement interpretation. McNemar's test was significant for Laboratory B sample set 1 compared with both sample sets from Laboratory A. Examination of the test results indicated that there were more positive results from Laboratory B for sample set 1 than from Laboratory A for both sample sets.

For virus isolation, the proportion of agreement was high $(\geq 91 \%)$ for both repeatability and reproducibility (Table 9). However, there was higher variability in the repeatability of virus isolation, particularly among Laboratory B sample sets. Laboratory B sample set 1 contained 5 more negatives than sample set 2 , creating an imbalance in the proportion of positives between sample set 1 in comparison

Table 7. Diagnostic sensitivities and specificities of the VHSV RT-qPCR and virus isolation as tested in Laboratory A using the pseudo-gold standard for the 2 groups of repeated samples. +: VHSV positive; -: VHSV negative

\begin{tabular}{|c|c|c|c|c|c|c|}
\hline \multirow[t]{3}{*}{ Sample set } & \multicolumn{4}{|c|}{ Pseudo-gold standard, test result } & \multirow{2}{*}{\multicolumn{2}{|c|}{$\begin{array}{c}\text { Diagnostic test performance } \\
\text { (95\% exact binomial confidence interval) }\end{array}$}} \\
\hline & \multirow{2}{*}{,++} & \multirow{2}{*}{,--} & \multirow{2}{*}{,-+} & \multirow{2}{*}{,+-} & & \\
\hline & & & & & Sensitivity (\%) & Specificity (\%) \\
\hline Virus isolation set 1 & 28 & 68 & 4 & 0 & $100(87.70,100)$ & $94.40(86.40,98.50)$ \\
\hline Virus isolation set 2 & 28 & 68 & 4 & 0 & $100(87.70,100)$ & $94.40(86.40,98.50)$ \\
\hline RT-qPCR set 1 & 28 & 72 & 0 & 0 & $100(87.70,100)$ & $100(95,100)$ \\
\hline RT-qPCR set 2 & 27 & 72 & 0 & 1 & $96.40(81.70,99.90)$ & $100(95,100)$ \\
\hline
\end{tabular}

Table 8. Agreement and Kappa values for repeatability (within-laboratory agreement) and reproducibility (between-laboratory agreement) of the VHSV RT-qPCR. +: VHSV positive; -: VHSV negative

\begin{tabular}{|lcccccccc|}
\hline Comparison & \multicolumn{3}{c}{ Result (Test 1, Test 2) } & Agreement \\
&,$++(\%)$ & $\begin{array}{c}\text { Exact McNemar's } \\
\chi^{2} \text { p-value }\end{array}$ & $\begin{array}{c}\text { Kappa } \\
\text { 95 confidence } \\
\text { interval }\end{array}$ \\
\hline Lab A1, Lab A2 & 27 & 1 & 0 & 72 & 99.00 & 1.00 & 0.975 & $0.926-1.000$ \\
Lab B1, Lab B2 & 28 & 6 & 1 & 65 & 93.00 & 0.12 & 0.8383 & $0.724-0.953$ \\
Lab A1, Lab B1 & 28 & 0 & 6 & 66 & 94.00 & 0.03 & 0.8603 & $0.753-0.968$ \\
Lab A2, Lab B1 & 27 & 0 & 7 & 66 & 93.00 & 0.02 & 0.8358 & $0.720-0.952$ \\
Lab A1, Lab B2 & 27 & 1 & 2 & 70 & 97.00 & 1.00 & 0.9264 & $0.844-1.000$ \\
Lab A2, Lab B2 & 27 & 0 & 2 & 71 & 98.00 & 0.50 & 0.9504 & $0.882-1.000$ \\
\hline
\end{tabular}


Table 9. Agreement and Kappa values for repeatability (within-laboratory agreement) and reproducibility (between-laboratory agreement) for the virus isolation test. +: VHSV positive; -: VHSV negative

\begin{tabular}{|c|c|c|c|c|c|c|c|c|}
\hline \multirow[t]{2}{*}{ Comparison } & \multicolumn{4}{|c|}{ Result (Test 1, Test 2) } & \multirow{2}{*}{$\begin{array}{c}\text { Agreement } \\
(\%)\end{array}$} & \multirow{2}{*}{$\begin{array}{c}\text { Exact McNemar's } \\
\chi^{2} \mathrm{p} \text {-value }\end{array}$} & \multirow{2}{*}{ Kappa } & \multirow{2}{*}{$\begin{array}{c}95 \% \text { confidence } \\
\text { interval }\end{array}$} \\
\hline &,++ &,+- &,-+ &,-- & & & & \\
\hline Lab A1, Lab A2 & 30 & 2 & 2 & 66 & 96.00 & 1 & 0.9081 & $0.820-0.996$ \\
\hline Lab B1, Lab B2 & 23 & 0 & 5 & 72 & 95.00 & 0.063 & 0.8688 & $0.758-0.980$ \\
\hline Lab A1, Lab B1 & 23 & 9 & 0 & 68 & 91.00 & 0.004 & 0.7766 & $0.641-0.912$ \\
\hline Lab A2, Lab B1 & 23 & 9 & 0 & 68 & 91.00 & 0.004 & 0.7766 & $0.641-0.912$ \\
\hline Lab A1, Lab B2 & 28 & 4 & 0 & 68 & 96.00 & 0.125 & 0.9049 & $0.814-0.996$ \\
\hline Lab A2, Lab B2 & 28 & 4 & 0 & 68 & 96.00 & 0.125 & 0.9049 & $0.814-0.996$ \\
\hline
\end{tabular}

with the others. McNemar's test was significant for the reproducibility between the results of sample set 1 and the other sample sets from Laboratory A. Kappa values for repeatability for both laboratories and the reproducibility for the sample set 2 test results from Laboratory B compared with Laboratory A were all considered to be in almost perfect agreement.

Within- and between-laboratory variability of RT-qPCR $C_{\mathrm{t}}$ values

CCCs for all pairs of tests results that were reported as $C_{\mathrm{t}}$ values were all greater than 0.930 , indicating extremely close agreement between sample $C_{\mathrm{t}}$ values from the same fish. The absolute values of the mean difference between the test pairs (Bland and Altman's limits of agreement) ranged from 0.007 to 0.690 . The CCC and the mean differences are presented in Table 10. Fig. 6 presents the plot of the $C_{\mathrm{t}}$ CCC for the results from sample sets 1 and 2 from Laboratory A and is presented as an example of the plots of all test pairs. The very high CCC for all test pairs indicates that the reduced major axis is close to the line of perfect concordance and the data points are tightly clustered around the major axis. Thus, the accuracy and precision of the test pairs is very high. Fig. 7 presents the Bland and Altman's limits of agreement plot for the results from sample sets 1 and 2 from Laboratory A and

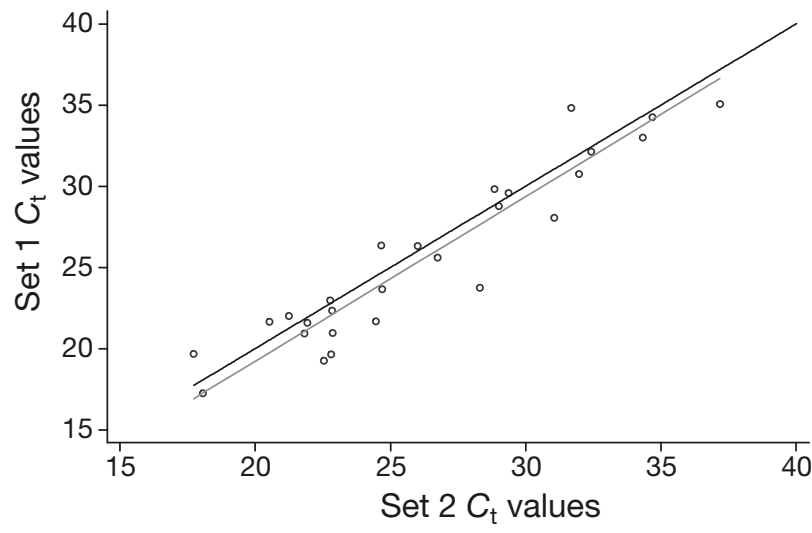

Reduced major axis _ Line of perfect concordance

Fig. 6. Plot of the $C_{\mathrm{t}}$ values for the pair of RT-qPCR assays representing the repeatability of the test within Laboratory A. The reduced major access is the linear regression line of the test results

is presented as an example of the plots. Visual examination of this plot and the plots of the other test pairs (not shown) reveal that there were no major outliers nor did the differences vary with the mean $C_{\mathrm{t}}$ value. Because some of the fish had some positive (with $C_{\mathrm{t}}$ values reported) and some negative results from the 4 replicate samples tested by RT-qPCR, the number of pairs used for these analyses was either 27 or 28.
Table 10. Reproducibility and repeatability as measured by concordance correlation coefficients (CCC; rho) and mean difference for test pairs (Bland and Altman's limits of agreement). Only fish that had both $C_{\mathrm{t}}$ values $\leq 38$ were compared because the RT-qPCR cut-off was 38

\begin{tabular}{|lccc|}
\hline Comparison & CCC $(95 \%$ CI $)$ & $\begin{array}{c}\text { Mean difference } \\
(95 \% \text { CI })\end{array}$ & $\begin{array}{c}\text { No. of pairs re- } \\
\text { porting } C_{\mathrm{t}} \text { values }\end{array}$ \\
\hline Lab A1, Lab A2 & $0.936(0.888,0.984)$ & $-0.690(-4.145,2.764)$ & 27 \\
Lab A1, Lab B1 & $0.954(0.919,0.988)$ & $-0.030(-3.413,3.354)$ & 28 \\
Lab A1, Lab B2 & $0.931(0.879,0.983)$ & $-0.020(-3.943,3.903)$ & 27 \\
Lab A2, Lab B1 & $0.932(0.880,0.983)$ & $0.656(-2.932,4.244)$ & 27 \\
Lab A2, Lab B2 & $0.940(0.894,0.985)$ & $0.670(-2.745,4.086)$ & 27 \\
Lab B1, Lab B2 & $0.943(0.901,0.985)$ & $0.007(-3.653,3.667)$ & 28 \\
\hline
\end{tabular}

\section{DISCUSSION}

The qPCR advantages of quick turnaround times, capacity for high throughput and high specificity that are gained over traditional diagnostics has rapidly increased the use of this technology in the detection of a range of viral, bacterial and parasitic pathogens of aquatic animals. With this increase in popularity, qPCR technology is quickly being sought as an alternative to traditional diagnos- 


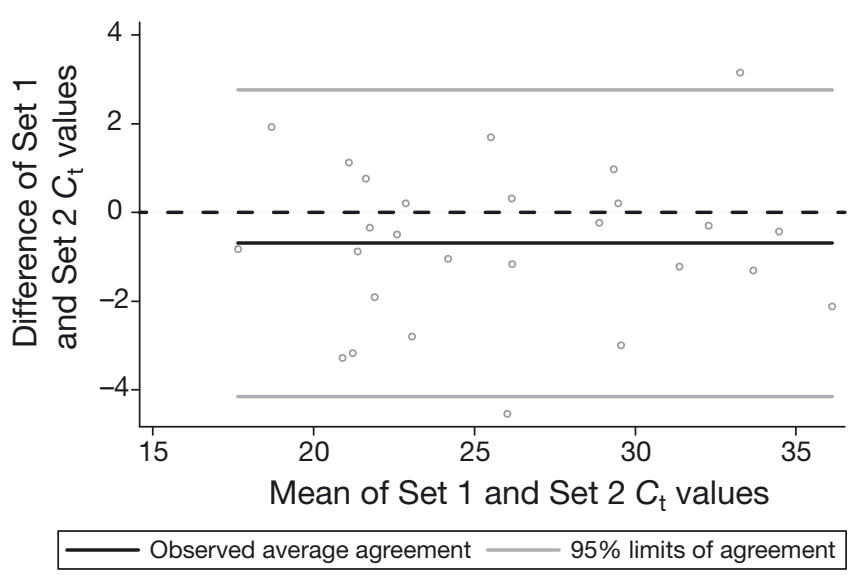

Fig. 7. Bland and Altman's limits-of-agreement plot of the differences in $C_{\mathrm{t}}$ values of the pair of RT-qPCR assays representing the repeatability of the test within Laboratory A. $y=0$ is the line of perfect agreement

tic methods. However, for qPCR to be implemented in a diagnostic setting, it is necessary that the assay is validated at both the analytical and diagnostic levels (Stages 1 and 2), ensuring confidence that the assay performs consistently and reliably in multiple laboratories, and in the hands of different staff (Hoorfar et al. 2004). In this study we developed a validated VSHV RT-qPCR assay that is fit for diagnostic purposes.

Prior to the diagnostic use of RT-qPCR for detection of VHSV, it is essential that the assay performs well analytically, containing both high sensitivity and specificity. The VHSV RT-qPCR assay described herein is specific, detecting only VHSV and not other finfish viruses that can co-occur within the infectious range of VHSV. The assay is also highly sensitive, with a reliable limit of detection of 100 VHSV N-gene copies. Empirical studies (Fig. 3) examining the minimum number of copies reliably detected by the VHSV RT-qPCR established a positive $C_{\mathrm{t}}$ cut-off value of 38 , thereby defining where the test method performance becomes insufficient for acceptable detection of VHSV, ultimately facilitating the interpretation of diagnostic samples that are at or near this limit. This positive threshold value allows for maximum diagnostic sensitivity without compromising specificity, thereby reducing the proportion of non-diseased animals that are falsely identified as diseased (Fig. S3 in the supplement). It is noteworthy that $C_{\mathrm{t}}$ calculations may differ depending on PCR platforms and associated algorithms, thus proficiency testing and independent limit of detection determinations using absolute standards are recommended to ensure that assays are working similarly among different laboratories.

For widespread use of VHSV RT-qPCR as a diagnostic tool, it is imperative that the assay not only be spe- cific but also universal in its detection of VHSV, such that all genetic variants of VHSV are recognized. Over the past several years multiple publications have demonstrated the use of qPCR to detect VHSV (Chico et al. 2006, Matejusova et al. 2008, Cutrin et al. 2009, Hope et al. 2010). One challenge posed by the use of these qPCR technologies for diagnostic purposes lies in their ability to detect all genetic variants of VHSV with a single assay. Development of a single primer/probe that universally detects VHSV has been complicated by the fact that VHSV maintains a high level of genetic heterogeneity that phylogenetically groups into 4 genotypes and multiple subtypes (Snow et al. 1999, Einer-Jensen et al. 2004, 2005). The assay described herein targets a highly conserved region of the $\mathrm{N}$ gene identified through extensive sequencing efforts undertaken in our laboratory. A single primer pair and TaqMan probe (set 2) targeting this region efficiently detected all 4 genotypes of VHSV, and did not crossreact with other sympatric aquatic viruses. The use of a single primer pair and probe simplifies assay components and eliminates the need to multiplex reactions to detect different VHSV strains. Additionally, the 2-step design of the universal VHSV RT-qPCR, which uses random hexamers to generate cDNA, affords the laboratory the option of archiving cDNA that can be screened for other RNA viruses at a later time point.

Use of qPCR technology in diagnostics also requires the assays to be transferable to multiple laboratories. Because of the highly technical nature inherent in qPCR methodologies, a high degree of variability in performance can exist among laboratories carrying out the same test (Noordhoek et al. 1996, Dequeker \& Cassiman 2000, Lemmer et al. 2004, Apfalter et al. 2005, Raggi et al. 2005, Ramsden et al. 2006). Thus, the universal VHSV RT-qPCR assay described in the present study was designed such that procedures would be easily transferable to other laboratories, reproducible and robust (i.e. perform well under different operating conditions). To facilitate assay transfer to multiple laboratories, commercially available kits were employed, thereby standardizing and streamlining the universal VHSV RT-qPCR procedure. An evaluation of test performance using proficiency panel testing revealed equivalent results by 9 technicians in 4 laboratories run under different conditions (Tables 4 \& 5), suggesting that the universal VHSV RT-qPCR assay is transferable and robust.

To determine assay reproducibility under conditions simulating a diagnostic disease investigation case, the universal VHSV RT-qPCR assay was further compared between 2 laboratories using a larger number of samples containing VHSV-infected and -uninfected specimens. Out of 100 samples analyzed using VHSV RTqPCR, the proportion of agreement between the 2 
laboratories was exceptional, ranging from 93 to $98 \%$. Moreover analyses of duplicate sample sets within laboratories revealed very little variation, (proportion of agreement: Laboratory A = 99\%, Laboratory B = 93\%), indicating that the universal VHSV RT-qPCR assay is not only reproducible but also very repeatable. The kappa statistic, which was used to demonstrate agreement beyond chance between test results (Landis \& Koch 1977), supported this high agreement. Bias due to an uneven proportion of positive test results and the prevalence of the tested population could have affected kappa (Sargeant \& Martin 1998, Dohoo et al. 2009). However, this bias was assessed by McNemar's test and the prevalence influence was minimized by using a group of fish with a VHSV prevalence that was neither too high or too low ( 30\%).

Ultimately, to determine whether the universal VHSV RT-qPCR assay is 'fit for intended purpose', the test was evaluated on diagnostic specimens obtained through experimental challenges. Diagnostic performance of the VHSV RT-qPCR assay, measured by DSe and DSp, was shown to be high and equivalent to the performance of the traditional methodology of virus isolation using cell culture. The comparable performance characteristics of the RT-qPCR and virus isolation tests achieved among the multiple testing labs suggests that the universal VHSV RT-qPCR assay described herein is suitable for VHSV diagnostic testing. However, it is important to note that these test performance comparisons were conducted utilizing samples that most closely mirror a VHS disease outbreak. Over the $11 \mathrm{~d}$ sampling time frame, Atlantic salmon injected with VHSV exhibited disease signs ranging from asymptomatic to severe clinical signs. Presumably, this population reflects a range of viral titers representative of an acute phase of VHS disease. During this acute phase, we speculate that VHSV is replicating and infectious, thereby facilitating the detection of VHSV on susceptible cell lines. The ease of culturability of VHSV in acutely infected specimens may in part explain the high diagnostic sensitivity of virus isolation observed in this study.

Continued validation of the universal VHSV RTqPCR assay will be necessary to evaluate and compare test performance characteristics of traditional methodologies under alternative conditions. For instance, test performance characteristics need to be evaluated in fish populations exhibiting chronic VHS disease or that are considered as 'carrier' populations. Detection of VHSV in such populations may not be readily detected using cell culture yet are detected via RT-qPCR, thereby resulting in higher sensitivities for RT-qPCR than by virus isolation. Such increased sensitivity of RT-qPCR over virus isolation has been reported by Hope et al. (2010). Alternative validation conditions may also warrant the use of other modeling approaches, such as latent class, to evaluate DSe and DSp as utilized by Nerette et al. (2008).

The potential for false positive results when performing RT-qPCR has hindered the widespread use of this methodology in diagnostic testing. In the present study, we demonstrated diagnostic specificities of $100 \%$, indicating that no VHSV-negative specimens were falsely identified as VHSV positive. Inclusion of a positive and negative control in each of the nucleic acid extraction, cDNA production and template amplification steps ensured that the RT-qPCR assay was run correctly and no cross-contamination occurred. Additionally, proficiency testing among laboratories facilitated the assessment of quality-control measures and the ability to adequately run the VHSV RT-qPCR assay prior to processing diagnostic specimens. Proficiency testing or external quality assessments of PCR-based diagnostics have proven invaluable in maintaining consistency in data and test result validity and undoubtedly aided in the high consistency of results both within and between laboratories reported herein.

In conclusion, the VHSV RT-qPCR assay described in this study provides universal detection of all genotypes of VHSV yet is highly specific, amplifying VHSV and not related aquatic viruses. Additionally, the VHSV RTqPCR assay is highly sensitive, maintaining operating performance characteristics equivalent to those of traditional cell culture detection methods, with the added advantage of obtaining results within a few hours rather than weeks. Lastly, the RT-qPCR assay is amenable to high throughput and is easy transferred to other labs, providing consistent and reliable results. The universal VHSV RT-qPCR assay is the national screening test for VHSV in Canada and has been used in National Aquatic Animal Health Program surveillance and survey efforts since 2007. Among 3 Canadian laboratories, the VHSV RT-qPCR test has been collectively performed on over 5000 diagnostic samples.

Acknowledgements. We thank S. Dawe for performing fish necropsies and P. Wright for contributing to the experimental design. This study was funded by the Centre of Expertise for Aquatic Animal Health Research \& Development, Fisheries and Oceans Canada.

\section{LITERATURE CITED}

Ammayappan A, Vakharia VN (2009) Molecular characterization of the Great Lakes viral hemorrhagic septicemia virus (VHSV) isolate from USA. Virol J 6:171

Apfalter P, Reischl U, Hammerschlag MR (2005) In-house nucleic acid amplification assays in research: How much quality control is needed before one can rely upon the results? J Clin Microbiol 43:5835-5841

Barnhart HX, Haber MJ, Lin LI (2007) An overview on assessing agreement with continuous measurements. J Biopharm Stat 17:529-569 
Batts WN, Arakawa CK, Bernard J, Winton JR (1993) Isolates of viral hemorrhagic septicemia virus from North America and Europe can be detected and distinguished by DNA probes. Dis Aquat Org 17:67-71

Betts AM, Stone DM (2000) Nucleotide sequence analysis of the entire coding regions of virulent and avirulent strains of viral haemorrhagic septicaemia virus. Virus Genes 20: $259-262$

> Bland JM, Altman DG (1986) Statistical methods for assessing agreement between two methods of clinical measurement. Lancet 1:307-310

Bruchhof B, Marquardt O, Enzmann PJ (1995) Differential diagnosis of fish pathogenic rhabdoviruses by reverse transcriptase-dependent polymerase chain reaction. J Virol Methods 55:111-119

> Chico V, Gomez N, Estepa A, Perez L (2006) Rapid detection and quantitation of viral hemorrhagic septicemia virus in experimentally challenged rainbow trout by real-time RTPCR. J Virol Methods 132:154-159

- Cohen JA (1960) A coefficient of agreement for nominal scales. Educ Psychol Meas 20:37-46

Cutrin JM, Olveira JG, Bandin I, Dopazo CP (2009) Validation of real time RT-PCR applied to cell culture for diagnosis of any known genotype of viral haemorrhagic septicaemia virus. J Virol Methods 162:155-162

Dequeker E, Cassiman JJ (2000) Genetic testing and quality control in diagnostic laboratories. Nat Genet 25:259-260

Dohoo IR, Martin W, Stryhn H (2009) Veterinary epidemiologic research, 2nd edn. VER Inc., Charlottetown

> Einer-Jensen K, Ahrens P, Forsberg R, Lorenzen N (2004) Evolution of the fish rhabdovirus viral haemorrhagic septicaemia virus. J Gen Virol 85:1167-1179

Einer-Jensen K, Ahrens P, Lorenzen N (2005) Parallel phylogenetic analyses using the $\mathrm{N}, \mathrm{G}$ or Nv gene from a fixed group of VHSV isolates reveal the same overall genetic typing. Dis Aquat Org 67:39-45

- Fijan N, Sulimanovic D, Bearzotti M, Muzinic D and others (1983) Some properties of the Epithelioma papulosum cyprini (EPC) cell line from carp Cyprinus carpio. Ann Inst Pasteur Virol 134:207-220

> Gagné N, Mackinnon AM, Boston L, Souter B, Cook-Versloot M, Griffiths S, Olivier G (2007) Isolation of viral haemorrhagic septicaemia virus from mummichog, stickleback, striped bass and brown trout in eastern Canada. J Fish Dis 30:213-223

- Garver KA, Dwilow AG, Richard J, Booth TF, Beniac DR, Souter BW (2007) First detection and confirmation of spring viraemia of carp virus in common carp, Cyprinus carpio L., from Hamilton Harbour, Lake Ontario, Canada. J Fish Dis 30:665-671

Hedrick RP, Batts WN, Yun S, Traxler GS, Kaufman J, Winton JR (2003) Host and geographic range extensions of the North American strain of viral hemorrhagic septicemia virus. Dis Aquat Org 55:211-220

> Hoorfar J, Wolffs P, Radstrom P (2004) Diagnostic PCR: validation and sample preparation are two sides of the same coin. APMIS 112:808-814

Hope KM, Casey RN, Groocock GH, Getchell RG, Bowser PR, Casey JW (2010) Comparison of quantitative RT-PCR with cell culture to detect viral hemorrhagic septicemia virus (VHSV) IVb infections in the Great Lakes. J Aquat Anim Health 22:50-61

Jensen MH (1963) Preparation of fish tissue cultures for virus research. Bull Off Int Epizoot 59:131-134

Kim SM, Lee JI, Hong MJ, Park HS, Park SI (2003) Genetic relationship of the VHSV (viral hemorrhagic septicemia virus) isolated from cultured olive flounder, Paralichthys olivaceus in Korea. J Fish Pathol 16:1-12

Kurath G, Leong JC (1985) Characterization of infectious hematopoietic necrosis virus mRNA species reveals a nonvirion rhabdovirus protein. J Virol 53:462-468

Kurath G, Garver KA, Troyer RM, Emmenegger EJ, EinerJensen K, Anderson ED (2003) Phylogeography of infectious hematopoietic necrosis virus in North America. J Gen Virol 84:803-814

Landis JR, Koch GG (1977) The measurement of observer agreement for categorical data. Biometrics 33:159-174

> Lannan CN, Winton JR, Fryer JL (1984) Fish cell lines: establishment and characterization of nine cell lines from salmonids. In Vitro 20:671-676

- Lemmer K, Donoso Mantke O, Bae HG, Groen J, Drosten C, Niedrig M (2004) External quality control assessment in PCR diagnostics of dengue virus infections. J Clin Virol 30:291-296

> Levey S, Jennings ER (1950) The use of control charts in the clinical laboratories. Am J Clin Pathol 20:1059-1066

Lin LI (1989) A concordance correlation coefficient to evaluate reproducibility. Biometrics 45:255-268

Lin LI (2000) A note on the concordance correlation coefficient. Biometrics 56:324-325

Lopez-Vazquez C, Dopazo CP, Olveira JG, Barja JL, Bandin I (2006) Development of a rapid, sensitive and non-lethal diagnostic assay for the detection of viral haemorrhagic septicaemia virus. J Virol Methods 133:167-174

Lorenzen N, Lorenzen E, Einer-Jensen K, Heppell J, Wu T, Davis H (1998) Protective immunity to VHS in rainbow trout (Oncorhynchus mykiss, Walbaum) following DNA vaccination. Fish Shellfish Immunol 8:261-270

> Lorenzen N, Lorenzen E, Einer-Jensen K, Heppell J, Davis HL (1999a) Genetic vaccination of rainbow trout against viral haemorrhagic septicaemia virus: small amounts of plasmid DNA protect against a heterologous serotype. Virus Res 63:19-25

Lorenzen E, Carstensen B, Olesen NJ (1999b) Inter-laboratory comparison of cell lines for susceptibility to three viruses: VHSV, IHNV and IPNV. Dis Aquat Org 37:81-88

- Lumsden JS, Morrison B, Yason C, Russell S and others (2007) Mortality event in freshwater drum Aplodinotus grunniens from Lake Ontario, Canada, associated with viral haemorrhagic septicemia virus, Type IV. Dis Aquat Org 76:99-111

> Mackay IM (2004) Real-time PCR in the microbiology laboratory. Clin Microbiol Infect 10:190-212

- Matejusova I, McKay P, McBeath AJA, Collet B, Snow M (2008) Development of a sensitive and controlled real-time RT-PCR assay for viral haemorrhagic septicaemia virus (VHSV) in marine salmonid aquaculture. Dis Aquat Org 80:137-144

McClure CA, Hammell KL, Stryhn H, Dohoo IR, Hawkins LJ (2005) Application of surveillance data in evaluation of diagnostic tests for infectious salmon anemia. Dis Aquat Org 63:119-127

Miller TA, Rapp J, Wastlhuber U, Hoffmann RW, Enzmann PJ (1998) Rapid and sensitive reverse transcriptase-polymerase chain reaction based detection and differential diagnosis of fish pathogenic rhabdoviruses in organ samples and cultured cells. Dis Aquat Org 34:13-20

Nerette P, Stryhn H, Dohoo I, Hammell L (2008) Using pseudogold standards and latent-class analysis in combination to evaluate the accuracy of three diagnostic tests. Prev Vet Med 85:207-225

Nishizawa $T$, Iida $H$, Takano $R$, Isshiki $T$, Nakajima $K$, Muroga K (2002) Genetic relatedness among Japanese, American and European isolates of viral hemorrhagic sep- 
ticemia virus (VHSV) based on partial G and P genes. Dis Aquat Org 48:143-148

Noordhoek GT, van Embden JD, Kolk AH (1996) Reliability of nucleic acid amplification for detection of Mycobacterium tuberculosis: an international collaborative quality control study among 30 laboratories. J Clin Microbiol 34: 2522-2525

OIE (Office International des Epizooties) (2009) Manual of diagnostic tests for aquatic animals, 6th edn. OIE, Paris

Raggi CC, Verderio P, Pazzagli M, Marubini E and others (2005) An Italian program of external quality control for quantitative assays based on real-time PCR with Taq-Man probes. Clin Chem Lab Med 43:542-548

Ramsden SC, Daly S, Geilenkeuser WJ, Duncan G and others (2006) EQUAL-quant: an international external quality assessment scheme for real-time PCR. Clin Chem 52: 1584-1591

Sargeant JM, Martin SW (1998) The dependence of kappa on attribute prevalence when assessing the repeatability of questionnaire data. Prev Vet Med 34:115-123

Schütze H, Enzmann PJ, Kuchling R, Mundt E, Niemann H, Mettenleiter TC (1995) Complete genomic sequence of the fish rhabdovirus infectious haematopoietic necrosis

Editorial responsibility: Mark Crane,

Geelong, Victoria, Australia virus. J Gen Virol 76:2519-2527

Shewhart WA (1931) Economic control of quality of the manufactured product. Van Nostrand, New York, NY

Snow M, Cunningham CO, Melvin WT, Kurath G (1999) Analysis of the nucleoprotein gene identifies distinct lineages of viral haemorrhagic septicaemia virus within the European marine environment. Virus Res 63:35-44

Snow M, McKay P, McBeath AJ, Black J and others (2006) Development, application and validation of a TaqMan real-time RT-PCR assay for the detection of infectious salmon anaemia virus (ISAV) in Atlantic salmon (Salmo salar). Dev Biol 126:133-145

Tebb T, Traxler GS, Evelyn T (1991) Lack of pathogenicity of a birnavirus isolated from Atlantic salmon in British Columbia. Aquac Update 54:1

Tordo N, Benmansour A, Calisher C, Dietzgen RG and others (2005) Family Rhabdoviridae. In: Fauquet CM (ed) Virus taxonomy. Eighth Report of the International Committee on Taxonomy of Viruses. Elsevier Academic Press, San Diego, CA

Westgard JO, Barry PL, Hunt MR, Groth T (1981) A multi-rule Shewhart chart for quality control in clinical chemistry. Clin Chem 27:493-501

Submitted: October 28, 2010; Accepted: February 7, 2011 Proofs received from author(s): May 25, 2011 